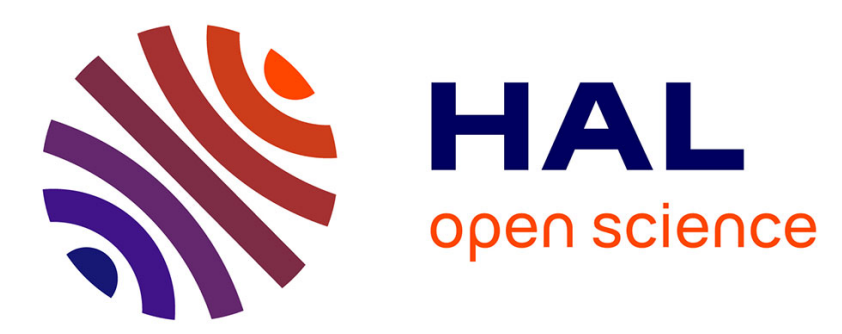

\title{
Structural Analysis of Poor Crystalline Ferrite Precursor, $\gamma$-FeOOH, Derived from Topotactic Hydrolysis of FeOCl
}

\author{
J.-H. Choy, J.-B. Yoon, K.-S. Han
}

\section{To cite this version:}

J.-H. Choy, J.-B. Yoon, K.-S. Han. Structural Analysis of Poor Crystalline Ferrite Precursor, $\gamma$ $\mathrm{FeOOH}$, Derived from Topotactic Hydrolysis of FeOCl. Journal de Physique IV Proceedings, 1997, 07 (C1), pp.C1-335-C1-336. 10.1051/jp4:19971134 • jpa-00254777

HAL Id: jpa-00254777 https://hal.science/jpa-00254777

Submitted on 1 Jan 1997

HAL is a multi-disciplinary open access archive for the deposit and dissemination of scientific research documents, whether they are published or not. The documents may come from teaching and research institutions in France or abroad, or from public or private research centers.
L'archive ouverte pluridisciplinaire HAL, est destinée au dépôt et à la diffusion de documents scientifiques de niveau recherche, publiés ou non, émanant des établissements d'enseignement et de recherche français ou étrangers, des laboratoires publics ou privés. 


\title{
Structural Analysis of Poor Crystalline Ferrite Precursor, $\gamma$-FeOOH, Derived from Topotactic Hydrolysis of FeOCl
}

\author{
J.-H. Choy, J.-B. Yoon and K.-S. Han* \\ Center for Molecular Catalysis, Department of Chemistry, College of Natural Sciences, Seoul National \\ University, Seoul 151-742, Korea \\ * Inorganic Chemistry Division, National Institute of Technology and Quality, Kyunggi-do 427-010, \\ Korea
}

\begin{abstract}
Layered compound FeOCl las iso-structure with $\gamma-\mathrm{FeOOH}$, which is considered as precursor of various magnetic materials in wet chemical synthesis. $\gamma-\mathrm{FeOOH}$ can be prepared by topotactic hydrolysis of FeOCl under a severe reaction condition $\left(60^{\circ} \mathrm{C}, 2\right.$ weeks). But the samples are often very poor in crystallinity under such a condition, so that the diffraction method can hardly be applicable. XAS spectroscopic studies at the Fe K-edge have been performed for FeOCl and its oxide/hydroxide derivatives. By comparison of XANES spectra for between $\gamma$-FeOOH and reference compounds such as $\mathrm{FeOCl}, \mathrm{Fe}_{2} \mathrm{O}_{3}$, and $\mathrm{Fe}_{3} \mathrm{O}_{4}$, it is confirmed that the iron octahedron becomes centrosymmetric as the chlorine atom was replaced with $\left(\mathrm{OH}^{-}\right)$. Detailed structure including bond angle as well as bond distance was obtained from Fe K-edge EXAFS analyses combined with powder X-ray diffaction for $\gamma$-FeOOH over long range up to $-6 \AA$ which is very large value in case conventional EXAFS curve-fitting.
\end{abstract}

\section{INTRODUCTION}

Iron oxychloride has a layered structure similar to $\gamma-\mathrm{FeOOH}$. Many intercalation or topochemical substitution complexes with unusual physicochemical properties have been well known up to now.[1] However, in such topochemical reaction complexes, it is very difficult to obtain single crystals since they are easily broken into fine powder due to the considerable elastic deformation during the reaction. Therefore, the structural characterization for intercalation/substitution complexes are highly restricted. In this regard, X-ray absorption spectroscopy (XAS) can be a powerful tool for determining the structure of such materials since it is very sensitive to the local environment around specific atoms, irrespective of crystallinity or dimensionality of solids.[2] Previously, we carried out successfully the EXAFS analyses for $\mathrm{FeOCl}$ and its methoxy substituent.[3] In the present work, we report the detailed structural changes around the iron atoms in $\gamma-\mathrm{FeOOH}$ derived from FcOCl using Fe K-edge XAS, and show how the crystal structure of low-dimensional compounds up to long distance of $6 \AA$ could be determined by the EXAFS method in combination with powder X-ray diffraction.

\section{EXPERIMENTAL SECTION}

Iron oxychloride was prepared from $\mathrm{Fc}_{2} \mathrm{O}_{3}$ and $\mathrm{FeCl}_{3}$ in sealed Pyrex tube at $370^{\circ} \mathrm{C}$ for a week by chemical vapor transport technique. Topochemical substitution of chlorine with $\mathrm{OH}^{-}$was carried out from finely ground FeOCl and a mixture of pyridine and water at $80^{\circ} \mathrm{C}$ for two weeks. The powder $\mathrm{X}$-ray diffraction patterns for $\mathrm{FeOCl}$ and $\gamma$-FeOOH were collected by a Philips PW1830 diffractometer using $\mathrm{Cu} \mathrm{K} \alpha$ radiation. X-ray absorption measurements were carried out with synchrotron radiation by using the EXAFS facilitics installed at beam line $10 \mathrm{~B}$ of the Photon Factory (the national laboratory for high energy physics, Tsukuba), operated at $2.5 \mathrm{GeV}$ with about $260 \sim 360 \mathrm{~mA}$ of stored current.

\section{XANES AND EXAFS DATA ANALYSIS}

The data analyses for experimental spectra were performed by a standard procedure as follows.[2] The inherent background in the data was removed by fitting a polynomial to the pre-edge region and then extrapolated through the entire spectrum from which it was subtracted. The resulting spectra. $\mu(E)$. were normalized to a unit jump for comparing the XANES features directly to one another. The absorption spectrum for the isolated atom. $\mu_{0}(\mathrm{E})$, was approximated by a cubic spline. The EXAFS function $\chi(E)$, was obtained as $\chi(E)=\left\{\mu(\mathrm{E})-\mu_{0}(\mathrm{E})\right\} / \mu_{1}(\mathrm{E})$ and then Fourier transformed in the range of $2.5 \sim 14.5$ $\AA^{-1}$ with a Hanning window of $\mathrm{d} k=0.5 \AA^{-1}$. In order to determine the structural parameters, nonlinear least-squares curve fitting was performed in the region of $R<6.3 \AA$ corresponding to the next nearest Fe along the $a$-axis using the $U W X A F S$ codc and theoretical curved wave ab initio EXAFS code FTFF 6 . [4] 


\section{Fe K-EDGE XANES}

XANES spectroscopy gives information on the local structurc and the elcctronic state of the iron atom. By comparison of preedge peak (due to $1 \mathrm{~s}--\rightarrow>3 \mathrm{~d}$ transition) intensities which reflect on the local geometry around $\mathrm{Fe}$ atoms for $\gamma-\mathrm{FeOOH}$ and those for reference compounds such as $\mathrm{FeOCl} . \mathrm{Fe}_{2} \mathrm{O}_{3}, \mathrm{Fc}(\mathrm{acac})_{3}$. and $\mathrm{Fe}_{3} \mathrm{O}_{4}$, it is confirmed that the iron octahedron becomes centrosymmetric as the chlorine atom was replaced with $(\mathrm{OH})$. The cvidence for the centrosymmetric iron environment was also shown in main peak region (due to $1 \mathrm{~s}--->4 \mathrm{p}$ transition), which is split as $\mathrm{p} \pi$ and po in $\mathrm{FeOCl}$ but does not in $\gamma$-FeOOH. On the other hand, the oxidation state of the iron was unchanged by the substitution reaction.

\section{Fe K-EDGE EXAFS}

Since $\gamma-\mathrm{FeOOH}$ derived from $\mathrm{FeOCl}$ has very poor crystallinity, we could obtain only the $b$-axis parameter $(b=13.5 \AA)$ from powder XRD. The Fourier transforms for the EXAFS spectra of $\mathrm{FeOCl}$ and $\gamma$-FeOOH are shown in Figure 1. As the substitution of $\mathrm{Cl}^{-}$with $\mathrm{OH}^{-}$, the peak dic to $\mathrm{Cl}^{-}$around $2 \AA$ disappeared and the first peak due to oxygen neighbors was highly enhanced. Because the local structure of $\gamma-\mathrm{FcOOH}$ is similar to $\mathrm{FeOCl}$ except for the stacking type[3], at first, the EXAFS curve fitting was carried out with the theoretical amplitude and phase functions calculated from FEFF6 assuming the oxygen atoms occupy completely the chlorine sites of the unit cell of FeOCl. In next step, the theoretical function was recalculated by using the $b$-axis paramcter from XRD and $a, c$-axis parameters from the tentative EXAFS fitting. In the final stcp. we could obtain the interatomic distances and Dcbye-Waller factors (Table 1) and calculate the fractional atomic coordinates. The final fitting results are shown in Figure $1(R$-space) and Figure $2(k$-space), respectively. As shown in Table 1. the fitted interatomic distance was well consistent with the crystallographic ones [5] within the error limit of EXAFS fits.

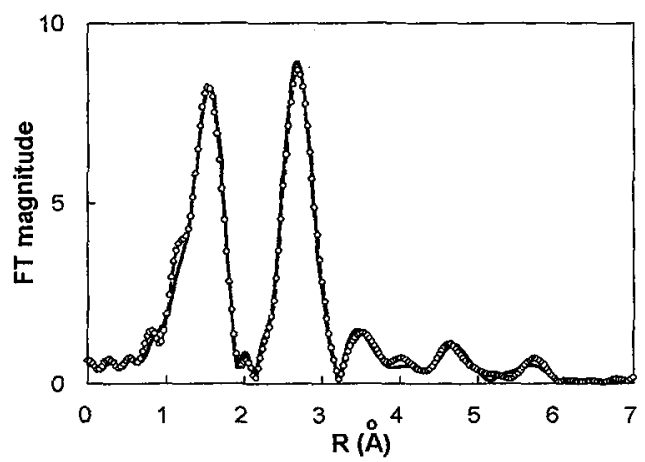

Figure 1. Comparison of the fitted spectra $(-)$ with the experimental data (o) for $\gamma$-FeOOH in $\mathrm{R}$ space.

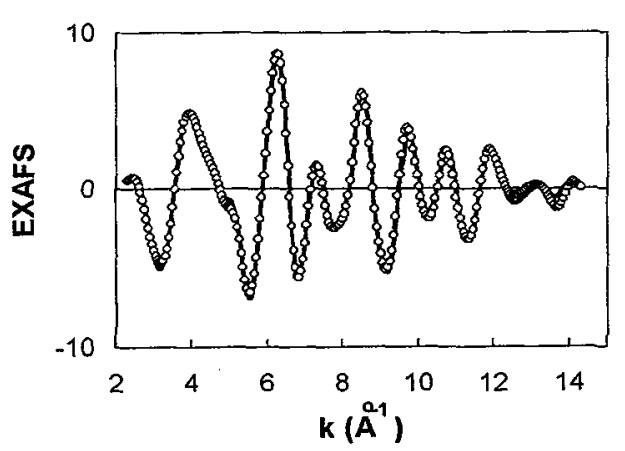

Figure 2. Comparison of the fitted spectra ( - ) with the experimental data (o) for $\gamma-\mathrm{FeOOH}$ in $k$ space.

Table 1. EXAFS fitting Results for $\gamma$-FeOOH. ${ }^{\text {a }}$

\begin{tabular}{|c|c|c|c|c|c|}
\hline Atom Pair ${ }^{b}$ & $\begin{array}{c}\text { Coordination } \\
\text { Number }^{c}\end{array}$ & $\begin{array}{c}\text { Distance } \\
(\AA)\end{array}$ & $\begin{array}{c}\text { Debye-Waller } \\
\text { Factor }\left(\times 10^{-3} \AA^{2}\right)\end{array}$ & $\begin{array}{c}\text { Energy Shift } \\
\left(\Delta \mathrm{E}_{0}\right)\end{array}$ & $\begin{array}{l}\text { Crystallographic } \\
\text { Distance }(\AA)^{\mathrm{c}}\end{array}$ \\
\hline $\mathrm{Fe}-\overline{\mathrm{O}_{1}}$ & 2 & 1.97 & 4.07 & -0.84 & 1.99 \\
\hline $\mathrm{Fe}-\mathrm{O}_{2}$ & 4 & 2.01 & 9.23 & -1.32 & 2.00 \\
\hline $\mathrm{Fe}-\mathrm{Fe} e_{1}$ & 6 & 3.07 & 7.57 & 1.03 & 3.06 \\
\hline $\mathrm{Fe}-\mathrm{O}_{3}$ & 4 & 3.68 & 6.00 & 2.18 & \\
\hline $\mathrm{Fe}-\mathrm{Fe}_{2}$ & 2 & 3.90 & 10.29 & -7.52 & 3.87 \\
\hline $\mathrm{Fe}-\mathrm{O}_{4}$ & 8 & 4.37 & 9.11 & -6.76 & \\
\hline $\mathrm{Fe}-\mathrm{Fe}_{3}$ & 4 & 4.96 & 14.61 & 8.01 & \\
\hline $\mathrm{Fe}-\mathrm{Fe}_{4}$ & 4 & 5.33 & 16.28 & 2.29 & \\
\hline $\mathrm{Fe}-\mathrm{Fe}_{5}$ & 4 & 6.15 & 12.93 & -7.68 & 6.12 \\
\hline
\end{tabular}

${ }^{\mathrm{a}}$ Fitting accuracy is about $0.02 \AA$ for distance and $25 \%$ for the Debye Waller factor, and fitting reliability $\Delta \chi^{2}=570[4] .{ }^{\mathrm{b}}$ The multiple scattering effect was considered only for $\mathrm{Fc}=\mathrm{Fe}_{3}=\mathrm{Fe}_{5}$, since such a effect is negligible for various possible pairs with the bond angles smaller than $150^{\circ}$. ${ }^{\circ}$ Coordination numbers are fixed to the values obtained from ref. [5].

\section{Acknowledgments}

The authors are grateful to Korea Research Foundation for the supporting research fund and also to Prof. M. Nomura for his kind assistance at BL10B.

\section{References}

[1] M.R.Halbert, Intercalation Chemistry, M.S.Whittingham and A.J.Jacobson Eds., Academic Press, New York, 1982, pp. 375-403,

[2] D. E. Sayers, B. A. Bunker, X-ray Absorption: Principles. Applications, Techniques of EXAFS, SEXAFS, and XANES, Koningsberger. R. Prins Eds. Wiley-Interscience, New York, 1988, pp. 211-253.

[3] J.-H. Choy, J.-B. Yoon, D.-K. Kim and S.-H. Hwang. Inorg. Chem., 34 (1995) 6524-6531.

[4] J. Mustre de Leon, J. J. Rehr, S. I. Zabinsky, Phys. Rev. B 44 (1991) 4146.

[5] F.J. Ewing, J. Chem. Phys., 3 (1935) 420-424. 